\title{
STUDY REGARDING THE IDENTIFICATION OF THE PROMOTIONAL METHODS FOR ALBA IULIA CITY AS A TOURISTIC DESTINATION
}

\author{
Moisă Claudia Olimpia \\ Lazea Ruxandra ${ }^{2}$
}

\begin{abstract}
This scientific paper has as main objective the identification of the main promotional methods that can be used to promote Alba Iulia City as a touristic destination, more exactly of the touristic resources that are present in the locality with the purpose of attracting a large number of Romanian and foreign tourists with the help of traditional and on-line promotion methods. The present study will be focused mainly on the largest Vauban Citadel from East and South East Europe. In order to identify the promotional methods that are most suitable to promote the Alba Iulia City as a touristic destination a research will be conducted using a questionnaire.
\end{abstract}

\section{Introduction}

Domestic and international tourism is a highly competitive environment with many destinations that offer more or less the same product; therefore in order to stand out the tourist destinations should be highly promoted in order to attract more tourists. In such a context, we considered necessary this research that aims to identify the best methods to promote a Romanian tourism destination, namely Alba Iulia city.

Among the tourist attractions and resources the city has AI is remarkable cultural heritage elements, namely: Alba Carolina medieval castle (built between $1715-1738$ is the largest city in Romania), St. Michael Roman Catholic Cathedral (most valuable roman architectural monument from Transylvania, dated sec. XI, place that holds two records: is the oldest and also the longest $93 \mathrm{~m}$ in shaft cathedral from Romania), Coronation Cathedral - built with the support of the Royal House of Romania during 1921-1922, in which on October 15, 1922 took place coronation ceremony of King Ferdinand and Queen Mary as sovereigns of Great Romania.

National Museum, Union Hall. There are some components of the anthropogenic patrimony less known and valued in terms of tourism, such as: Library Batthyaneum - established in July 31, 1798 on the initiative of the Roman Catholic Bishop of Transylvania Ignatius Batthyány and keeps more than 50,000 books, 19,000 documents, 1,230 manuscripts and nearly 600 incunabula (sec.IX), synagogue and cemetery Hebrew, Roman Catholic Episcopal Palace, Museikon, proving the existence of archaeological remains of a settlement inhabited by the Gauls before the arrival of the Romans discovered inside the former Roman fort at Apulum, etc. Or, to put in value such touristic objectives it requires promoting tourism.

In addition, Alba Iulia city as a tourist destination must be integrated into a much larger area in terms of territory respectively the surroundings within a radius of $100 \mathrm{~km}$ which enjoys a natural setting (Ampoiţa Keys, geological reservation from Râpa Red and Detunatele and Ramet Keys), but also hide priceless heritage and values of anthropogenic patrimony (Fortress Câlnic part of the UNESCO world heritage, Sebes Fortress ruins of Dacian fortresses, Ramet Monastery, the memorial house of Lucian Blaga from Lancrăm, the painting center of glass icons in the Laz, architecture, ethnography and folklore, habits and traditions specific to the village from Alba

\footnotetext{
1 "1 Decembrie 1918" University of Alba Iulia, Romania

2 "1 Decembrie 1918" University of Alba Iulia, Romania
} 
County). All this allows the development and promotion of integrated tourism products that capitalize on as many components of the potential tourism from Alba Iulia area.

Alba Iulia city's image as a tourist destination has been marked in recent years, by the economic and social challenges that have increased the number of tourist arrivals and the emergence of new investments in the specific market. The number of tourists registered in accommodation in the units surrounding Alba Iulia city has grown steadily in recent years, reaching in 2015 at 62634 people (NIS, 2016). Only exhibitions from National Union Museum and Hall of Unification in Alba Iulia were visited in 2016 by 167200 people (http://viziteazaalbaiulia.ro/muzeul-national-al-unirii-printre-cele-mai-vizitate-muzee-din-romania/) (the figure is one impressive and place the institution on the selected list of the most popular museums from our country).

Regarding the current promotion of Alba Iulia city as a tourist destination, we can say that it has a relatively intense activity. More specifically, it is about:

- written publicity, oral or online with the shape of various brochures, audio-video materials developed by Alba Iulia City Hall, tour guide of Alba County developed by Alba County Council (published in Romanian and English) and distributed among professionals or tourists interested in Alba Iulia as a holiday destination; the existence of the National Centre for Information and Tourist Promotion belonging to Alba Iulia City Hall and an official tour blog launched by the same institution

- Participation in fairs and promotional events with tourist characters (International Tourism Fair of Romania organized biannually in Bucharest, Tourism Fair "Ferien Messe" in Vienna)

- Organizing an extremely high range of different events such as music festivals or events dedicated to the City Days or to the Citadel Days, cultural and gastronomic events, etc. that attract potential tourists on a geographically region quite large, even from abroad

- Participation of the most important players on the local market at various tourism or other events (Alba Iulia City Hall, Center for Information and Tourism Promotion of Alba Iulia city, University "1 Decembrie 1918" from Alba Iulia; Caravan "Managing destinations: online and offline "conducted by ANT and Google Romania)

- Involvement of local authorities and other interested peoples in various projects, domestic or international Tourist information (project Divertimento consists of a consortium of 7 partners foreign and Romanian in which Alba Iulia participates as pilot city for the implementation of project activities, create tools for promotion in November including the creation of interactive games - EUROTHENTICA, the cultural Heritage Route - which will be presented at the Tourism Fair in Berlin in 2017; the "cultural routes in the lower and middle Danube" conducted by the National Tourism Authority, 2012-2013 - Alba Iulia in the city include Roman emperors Route, along Sarmisegetuza Ulpia Traiana, Adamclisi, Histria and Rosia Montana (http://ziarulunirea.ro/alba-iulia-oras-pilot-pentru-promovarea-turistica-neconventionala-382414/);

- Promoting in various specialized sites abroad; eg., site of tourist guides global brand "Rough" published in December 2016 a top ten destinations which can be visited with little money in 2017. Transylvania listed third in the ranking, and the city of Alba Iulia listed in the Carpathian mountains places worth visiting along with Brasov, Sibiu, Sighisoara, Cluj Napoca Apuseni Mountains Retezat (https://www.roughguides.com/features/).

As recognition of the efforts of tourism planning, Alba Iulia obtained in 2012 distinction EDEN for the theme tourism and regeneration of physical sites, given into the project "European Destinations of Excellence" - EDEN launched by the European Commission in 2006 whose main objective is increasing the visibility of non-traditional destinations (http://ec.europa.eu/growth/tools-databases/eden_en). Also, Alba Iulia city is the first city in Romania which aims to become "smart" until 2018 and was awarded at the "Romanian Tourism 
Gala" (2016), as the "first city with tourism brand (http://viziteazaalbaiulia.ro/orasul-in-careviitorul-prinde-radacini-premiat-la-gala-turismului-romanesc-2016/).

\section{Literature review}

Destination marketing refers to a management process through which the national tourist organizations and/or tourist enterprises identify their selected tourists, actual and potential, communicate with them to ascertain and influence their wishes, needs, motivations, and likes and dislikes, on local/rural, regional, national and international levels, and to formulate and adapt their tourist products accordingly with a view to achieving optimal tourist satisfaction, thereby fulfilling their objectives. Tourism destinations are probably among the most difficult "products" to market, involving large numbers of stakeholders and a brand image. (The International Labour Office, 2012.).

Promoting the tourism destination in the right and best possible way is today one of vital marketing activities of all Destination Management Organisations. Only successful promotion can entice and attract potential travellers to visit the destination (Ivo Mulec, 2010).

On tourism market, tourists face a wide range of holiday opportunities (Hosany et al, 2006) offered by various tourist destinations. For a destination to be recognized by potential tourists, it takes a good position on the market, which can be achieved on a recognized solid brand image. According to Kotler and Armstrong (2010), positioning of a touristic destination can best be described as the act of designing the offer and its image so that it occupies a distinct and appreciated place in the targeted tourist mind.

Nworah (2006) posits the idea that in order to attract visitors to a certain place, the touristic destination must differentiate itself from other competitive destinations with something different (quoted by Chikafu Jesc et al, 2014). In creating the image of a tourist destination very important are the views of actors in tourism (Bjork et al 2012).

\section{Obtained results}

The purpose of the research presented in this paper is to investigate the most appropriate methods of promotion that can be used to promote Alba Iulia City as a touring destination on both national and international market.

In order to accomplish the established purpose we have identified the following objectives:

- Identification of the respondents opinion on the methods currently used for promoting Alba Iulia City as a touring destination.

- Identify the preferences of respondents in terms of promotional methods.

- Identify the degree of attention given by the respondents to certain promotional methods.

- Identification of the frequencies of different promotional methods on which respondents came into contact.

- Identify the period of time when the respondents prefer receive notifications about different tourism attractions.

- Identify the number of times the respondents heard about certain tourism attractions from Alba Iulia due to promotional methods.

The target population taken into consideration in this research is an active population who is permanently connected to at least one of the promotional methods investigated in the present research, is a population that is willing to explore different touristic attractions and to find out more about the history of the touristic attractions. 
The present research is constructed as a quantitative one and the instrument used to collect the information is the questionnaire. After we conducted the research we obtained a number of 84 questionnaires. The obtained results are presented in the following section.

The first question investigated the respondents about the numbers of visits in the Alba Iulia City in the touristic purpose.
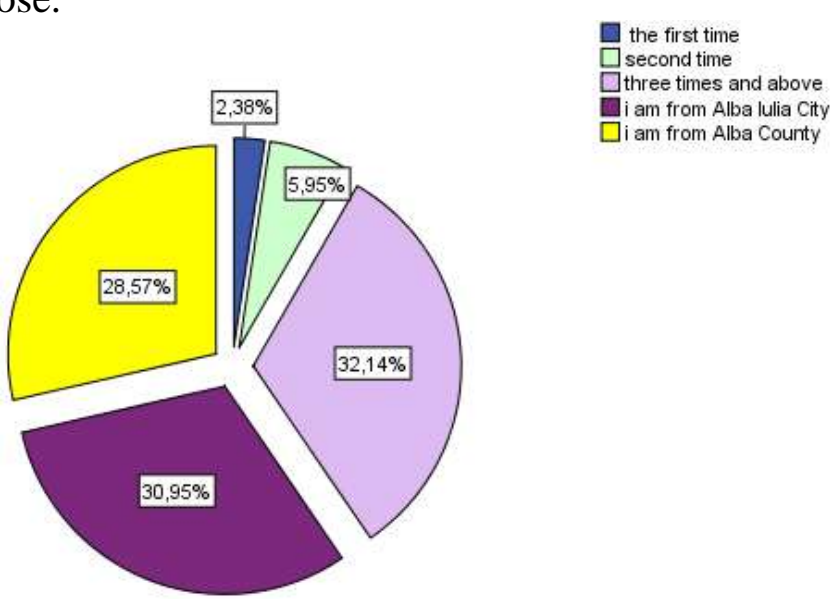

Figure 1: Numbers of visits

Source: author`s computation

From the obtained results we can see that the most significant result obtained is $32,14 \%$ given by the respondents that visited Alba Iulia city in touristic purpose more than three times. Due to this result we can say that Alba Iulia City has a significant rate of return from the tourists.

The second question investigated the promotional methods that attracted attention from the tourists in 2016. The investigated methods were the following: facebook, e-mail, travel web sites, tv, radio, banners, posters.

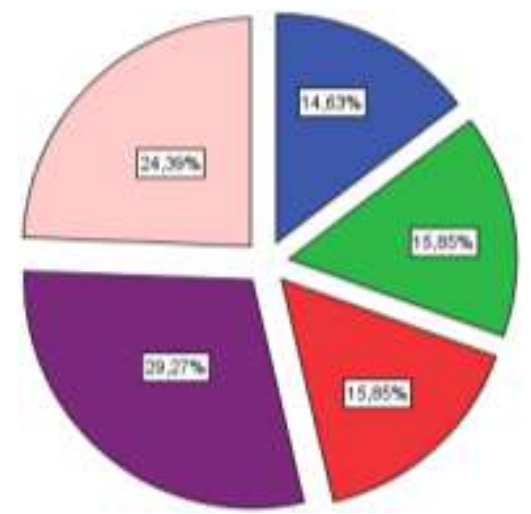

Figure 2: attention from Facebook

Source: author`s computation

From the results we can observe that $53,66 \%$ from the total number of respondents considered Facebook as a method that attracted their attention regarding Alba Iulia City a touristic destination. 


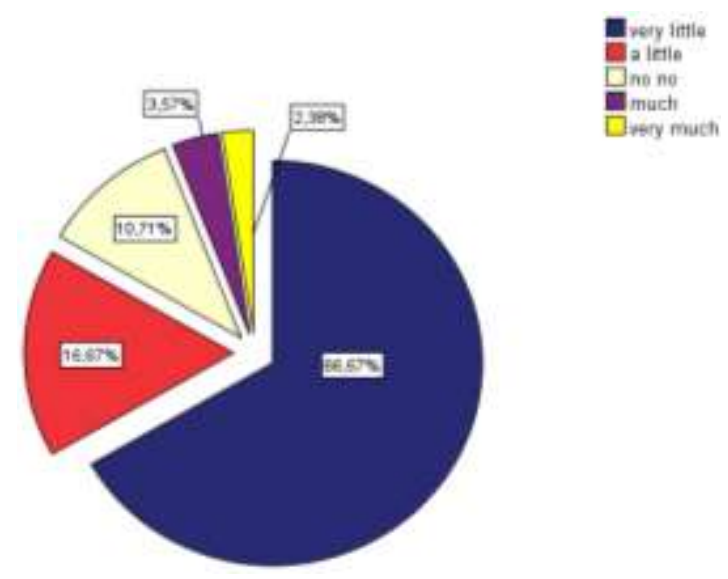

Figure 3: Attention from e-mail

Source: author`s computation

$66.67 \%$ from the total numbers of the respondents consider that e-mail did not perform any attraction to them. We can conclude that e-mail it is not an efficient method for promoting Alba Iulia City as a touristic destination. That result can be a consequence to the increased number of different e-mails that fill up the inbox daily.

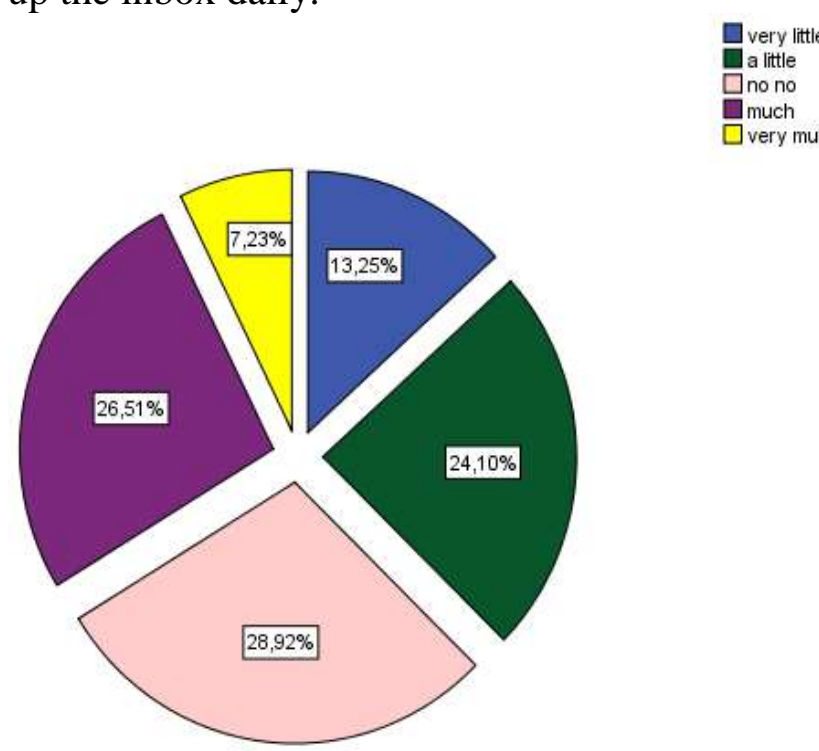

Figure 4: Attention from travel web sites

Source: author`s computation

From the results we can see that $28,29 \%$ from the respondents couldn't identify the level of attention perceived from travel web sites. $26,51 \%$ affirmed that travel web sites attracted their attention in a certain way. 


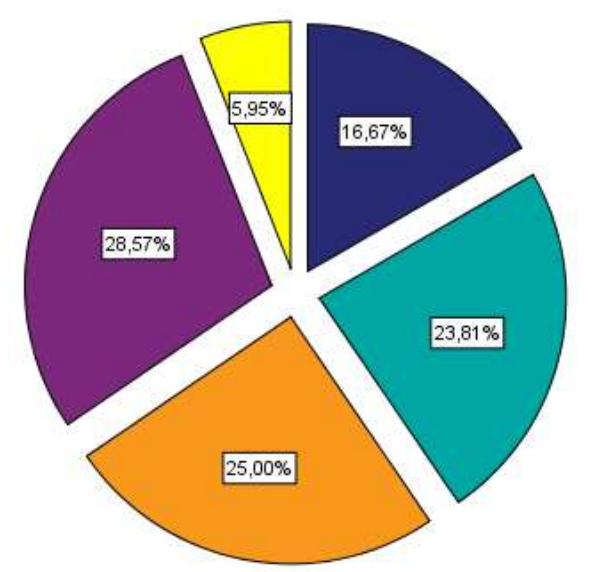

Figure 5: Attention from tv

Source: author`s computation

From the results we can observe that $28,57 \%$ from the respondents considered that tv had an role in the attraction perceived by the consumers regarding Alba Iulia city as touristic destination. $25 \%$ couldn't identify the level of the attraction experienced by the tv. $23,81 \%$ from the total number of respondents consider that the tv had a little role in constructing the level of attraction.

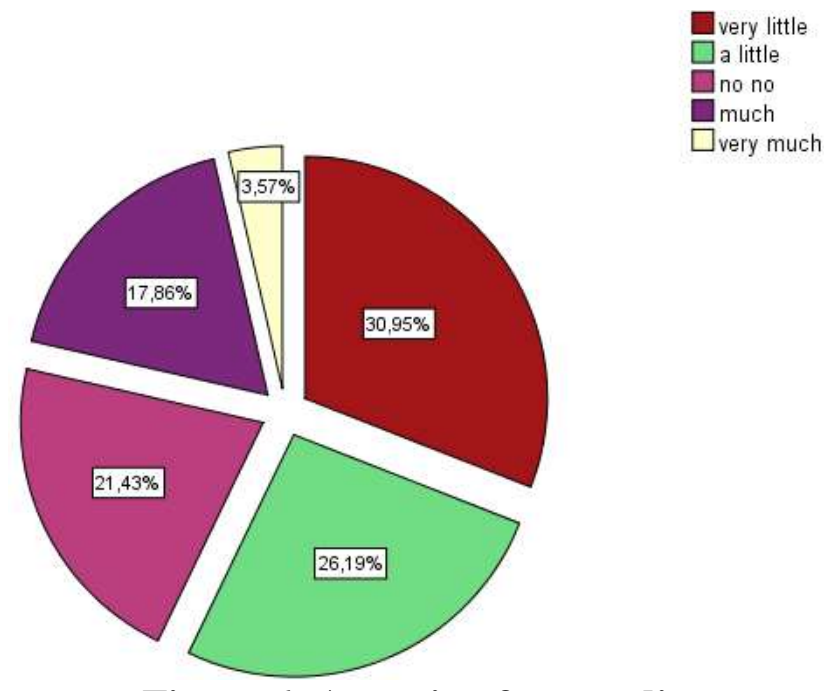

Figure 6: Attention from radio

Source: author`s computation

$30,95 \%$ from the respondents consider that promotion made on radio had little influence in the attention level perceived by them regarding Alba Iulia city as touristic destination and 26,19\% consider that the promotional efforts made using radio had a little impact on their attention. 21,43\% from the respondents couldn't specify the level of attraction felt after coming in contact with this promotional method. 


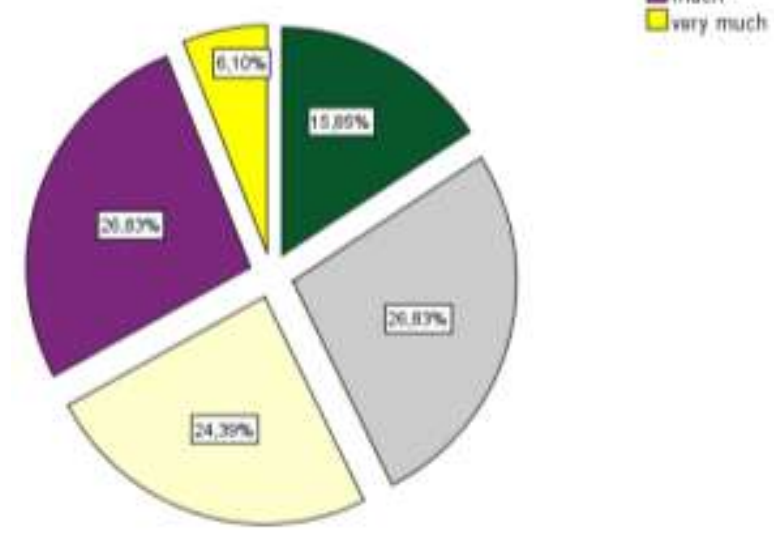

Figure 7: Attention from banners

Source: author`s computation

From the results obtained we can observe that an equal percentage $(26,83 \%)$ is found on a little influence and on an important influence of the banners on the consumers attention towards the promotion of Alba Iulia City as touristic destination. 24,39\% of the respondents couldn't specify the level of the influence given by the banners in this process.

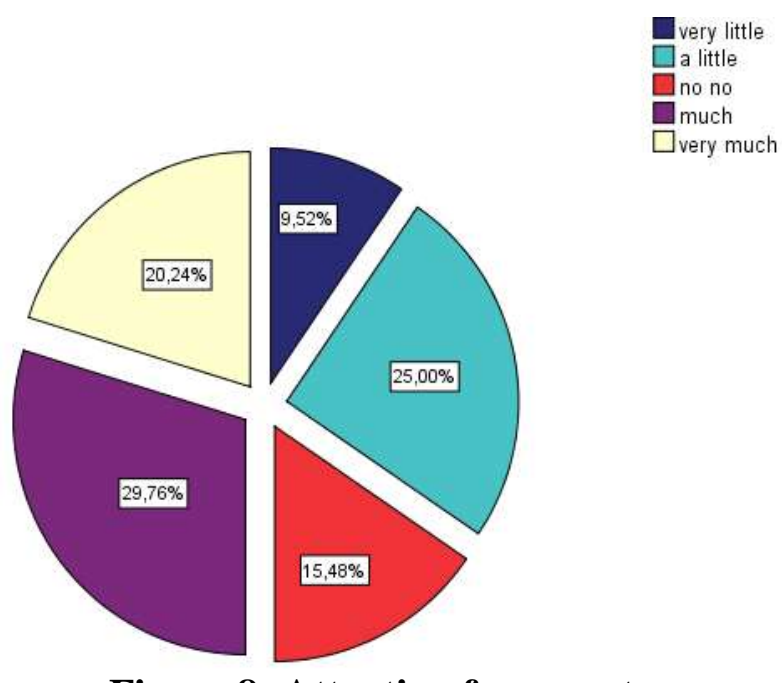

Figure 8: Attention from posters

Source: author`s computation

Posters are considered as an important method for attracting attention on Alba Iulia City as a touristic destination for $50 \%$ of the total number of respondents. For $25 \%$ of them this method is considered as having a small level of attractiveness.

The third question investigated the respondents' opinion about the most important method, in their point of view, for promoting Alba Iulia city as a touristic destination. They were asked to give their opinion on the following methods: facebook, e-mail, travel web sites, tv, radio, banners, posters and word of mouth promotion. 


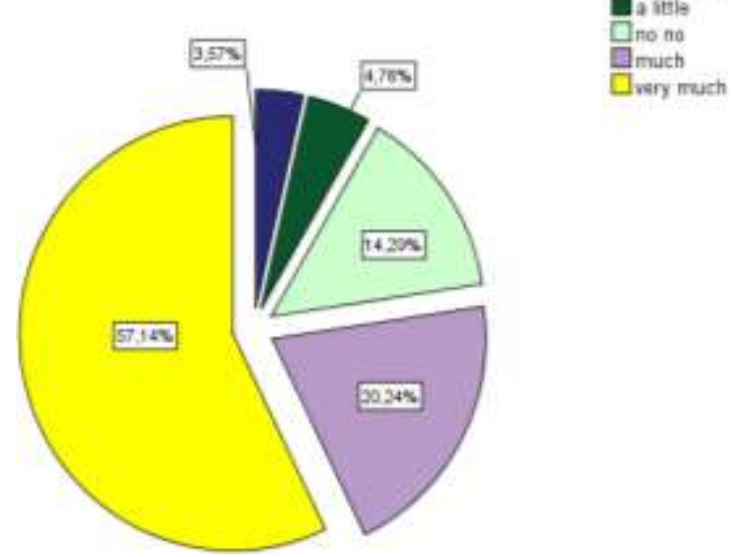

Figure 9: Facebook importance

Source: author`s computation

Facebook is considered as being the most important source of information by $57,14 \%$ from the total number of responses. 20,24\% from the total number of responses consider Facebook as an important source of information when it comes to finding out information about Alba Iulia city as a touristic destination.

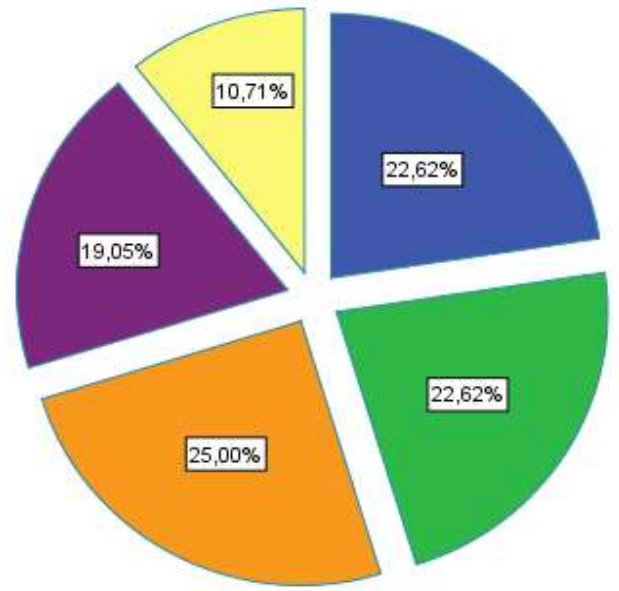

Figure 10: e-mail importance

Source: author`s computation

From the obtained results we can observe that $25 \%$ from the total number of respondents couldn't form an opinion about the importance of e-mail promotion for Alba Iulia city. 22,62\% consider that it is not an important method for performing promotional activities and 19,05\% consider that it is an important method. 

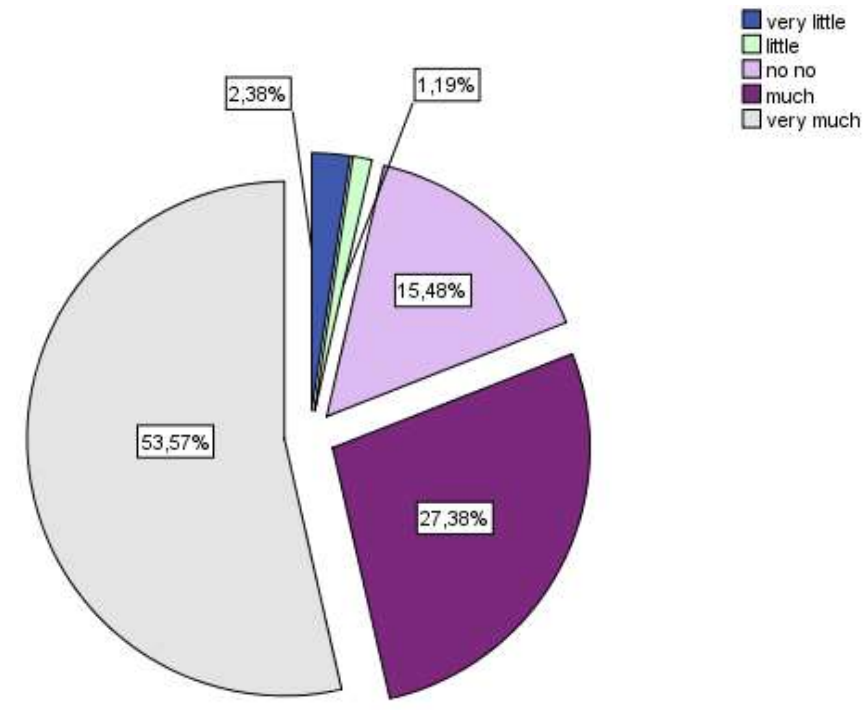

Figure 11: Travel web sites importance

Source: author`s computation

Promotion through travel web sites is considered as being a very important method for promoting Alba Iulia city by 53,57\% from the total number of respondents and important for $27,38 \%$ of them.
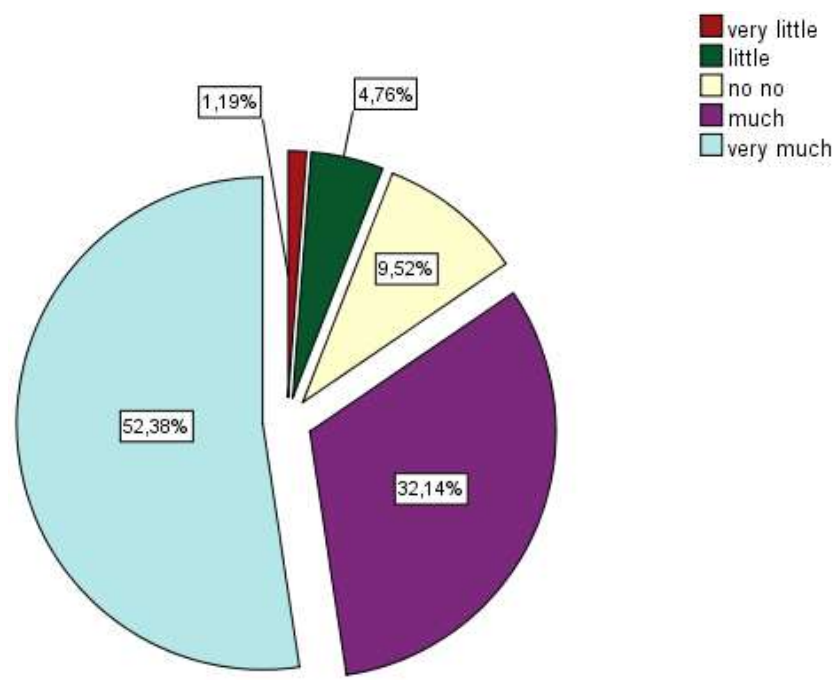

Figure 12: Tv importance

Source: author`s computation

$\mathrm{Tv}$ is considered as being a very important source of information by $84,52 \%$ from the total number of respondents. 


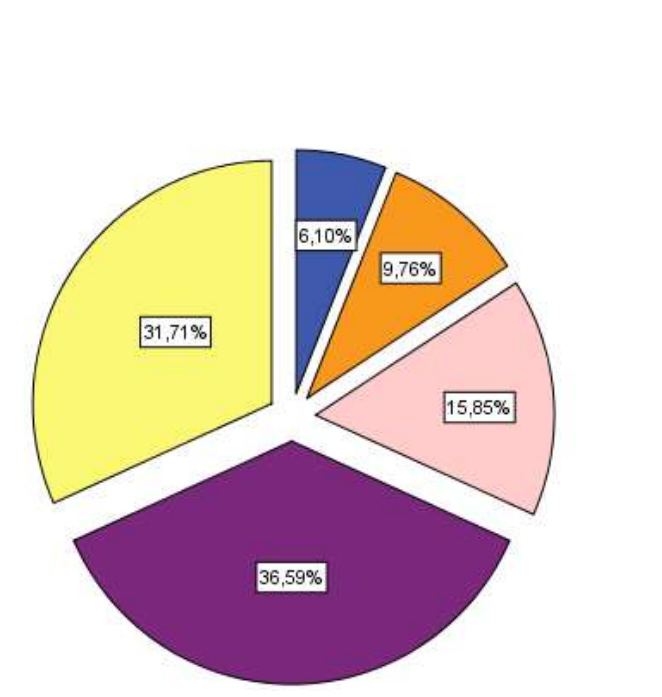

Figure 13: Radio importance

Source: author`s computation

From the obtained results we can observe that $68,3 \%$ from the total number of respondents consider that radio is an important method for promoting Alba Iulia city.

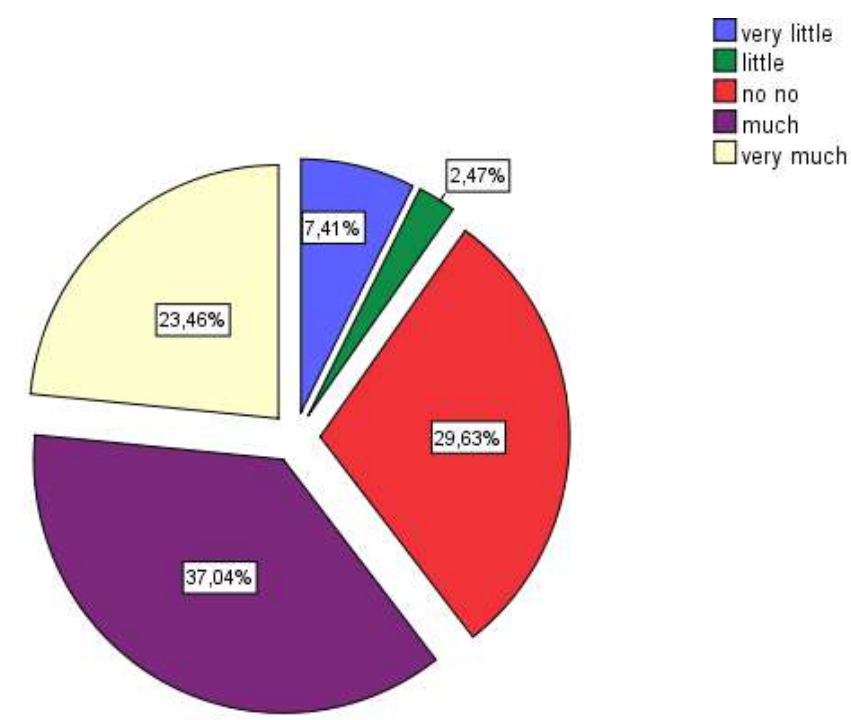

Figure 14: Banners importance

Source: author`s computation

As a method for performing promotional activities in tourism banners are considered important for promoting Alba Iulia city as a touristic destination by $60,8 \%$ from the total number of respondents. 


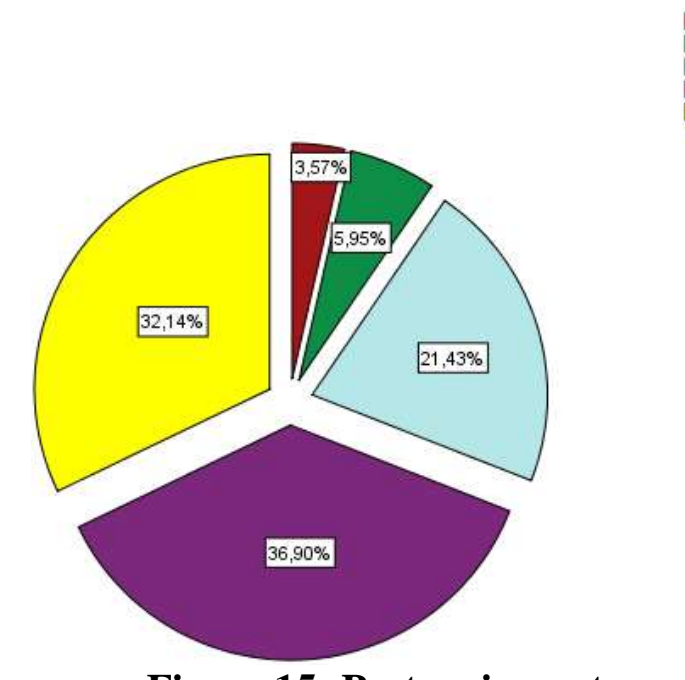

Figure 15: Posters importance

Source: author`s computation

From the obtained results we can observe that posters are considered an important method for promoting Alba Iulia city as a touristic destination by $36.90 \%$ and very important by $32,14 \%$ from the total number of respondents.

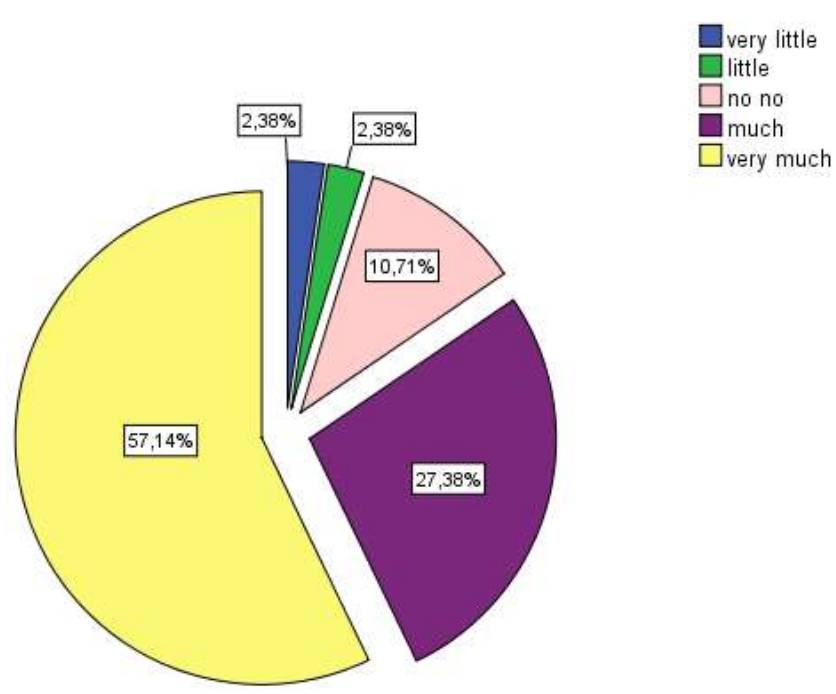

Figure 16: Word of mouth importance

Source: author`s computation

As a promotional method in tourism we can say that word of mouth represents the presentation of a touristic destination performed by a tourist that visited the location that it presents. From our obtained results we can see that $57,14 \%$ from the total number of the respondents consider this method as being very important for promoting Alba Iulia city as a touristic destination.

The next question investigated the efficiency of the promotional methods used to promote Alba Iulia city as a touristic destination. In this question the respondents were asked to give their opinion about the following methods: facebook, e-mail, travel web sites, tv, radio, banners, posters and word of mouth promotion. 

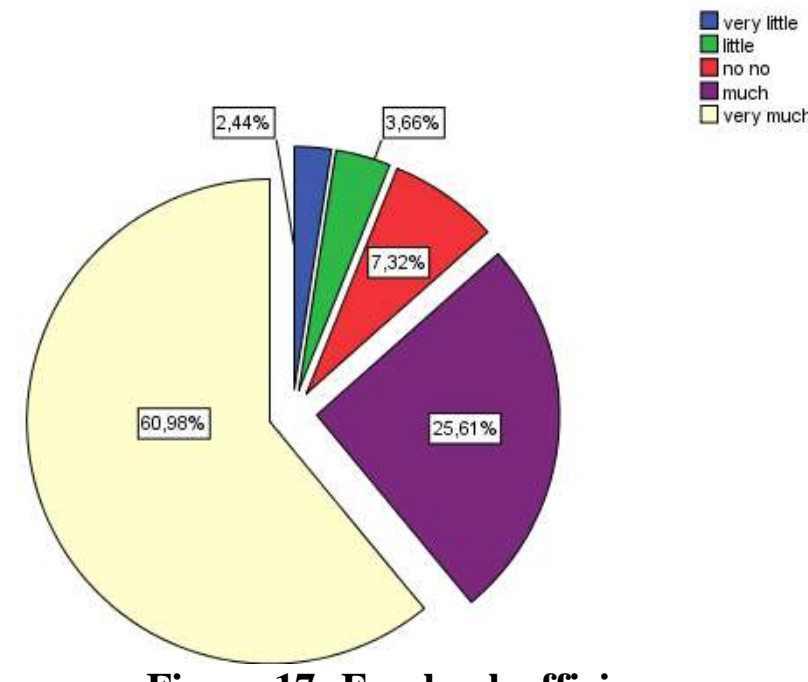

Figure 17: Facebook efficiency

Source: author`s computation

From the processed data we can observe that $60,98 \%$ of the respondents consider that Facebook is the most efficient method for promoting Alba Iulia city as a touristic destination and for $25,61 \%$ it is considered an efficient method for performing promotional activities for Alba Iulia city.
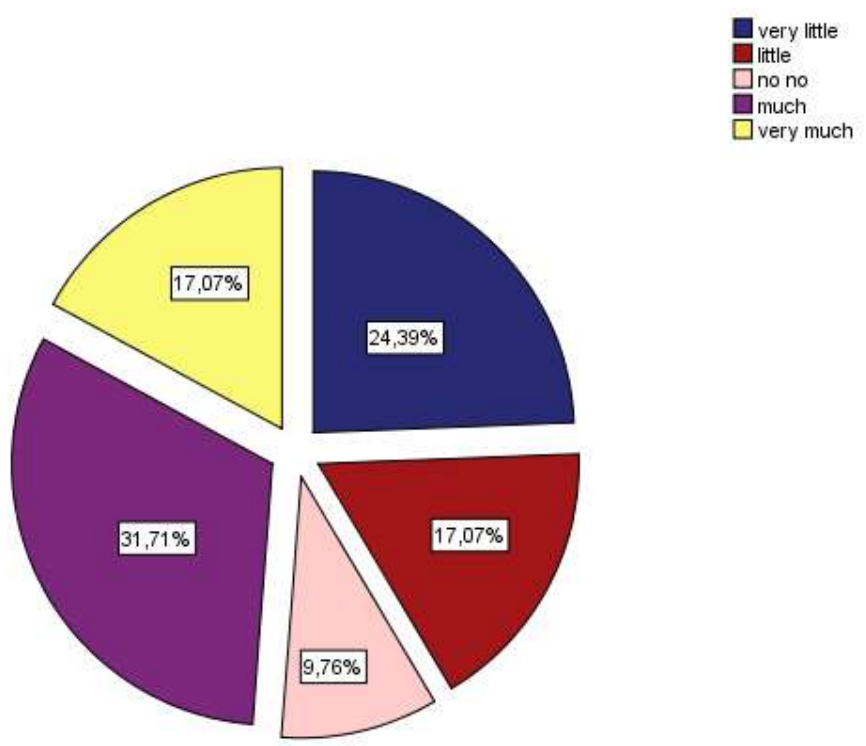

Figure 18: E-mail efficiency

Source: author`s computation

From the obtained results we can observe that $31,37 \%$ from the total number of respondents consider that e-mail is an efficient method for promoting Alba Iulia city as a touristic destination. $24,39 \%$ consider that it is not an efficient method for performing promotional activities. Also we can see that the result $17,07 \%$ it's found in two different opinions about this method's efficiency, namely as being very efficient and a little efficient. 

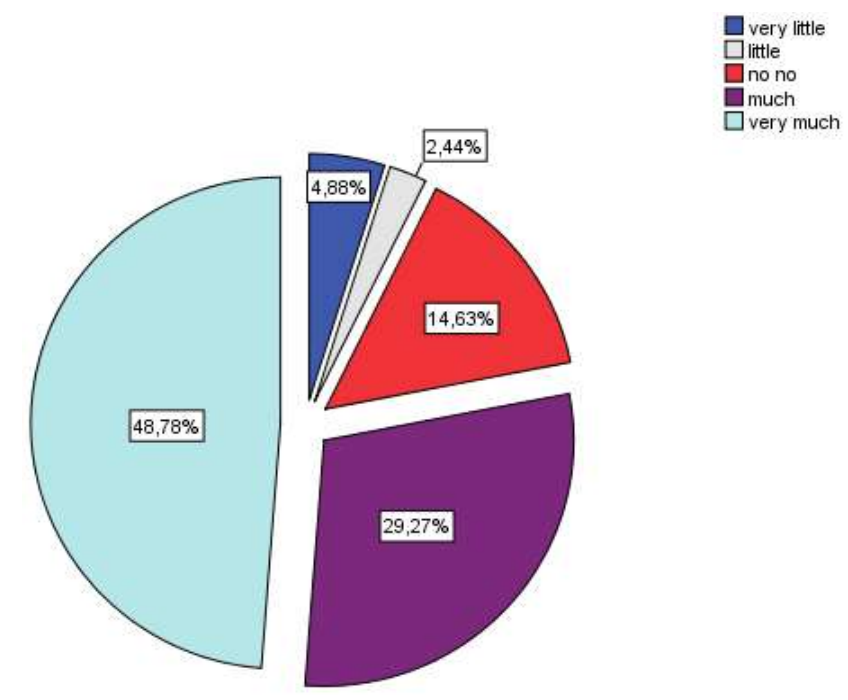

Figure 19: Travel web sites efficiency

Source: author`s computation

From the results we can observe that this promotional method is considered to be very efficient by $48,76 \%$ and efficient by $29,27 \%$ from the total number of respondents. This can be due to the fact that on a web site a visitor can see the full details of an touristic objective and can also see, if the web site allows, previous reviews about a certain touristic objective made by the tourists.
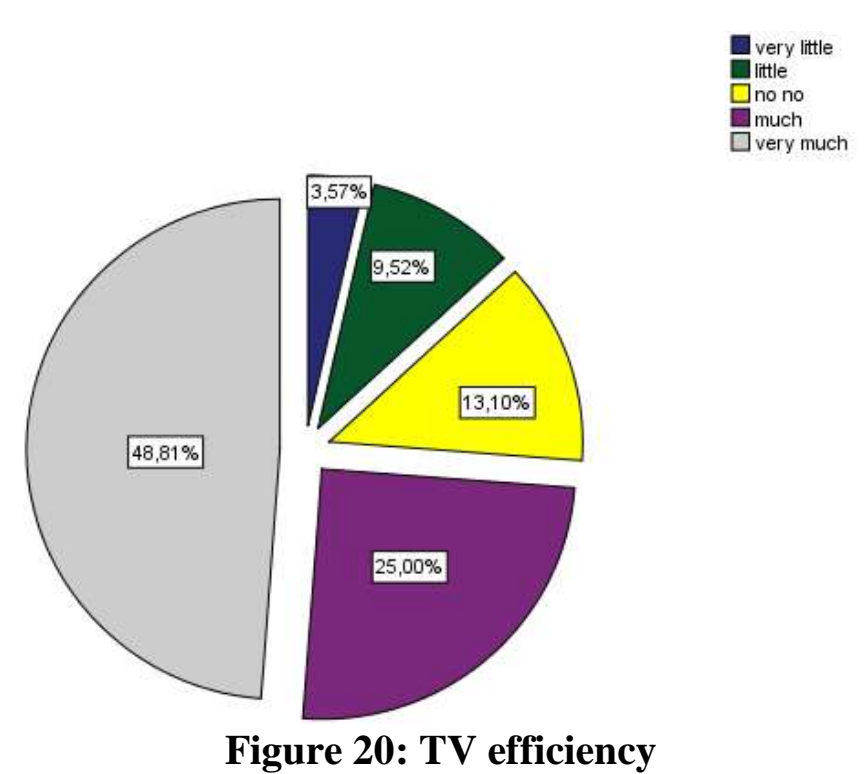

Source: author`s computation

For $73,81 \%$ from the total number of respondents $\mathrm{Tv}$ is considered to be an efficient method for promoting Alba Iulia as a touristic destination. This may be the result of the fact that this method of promotion combines both image and sound and allows the audience to form a complete image about the promoted touristic objective. 


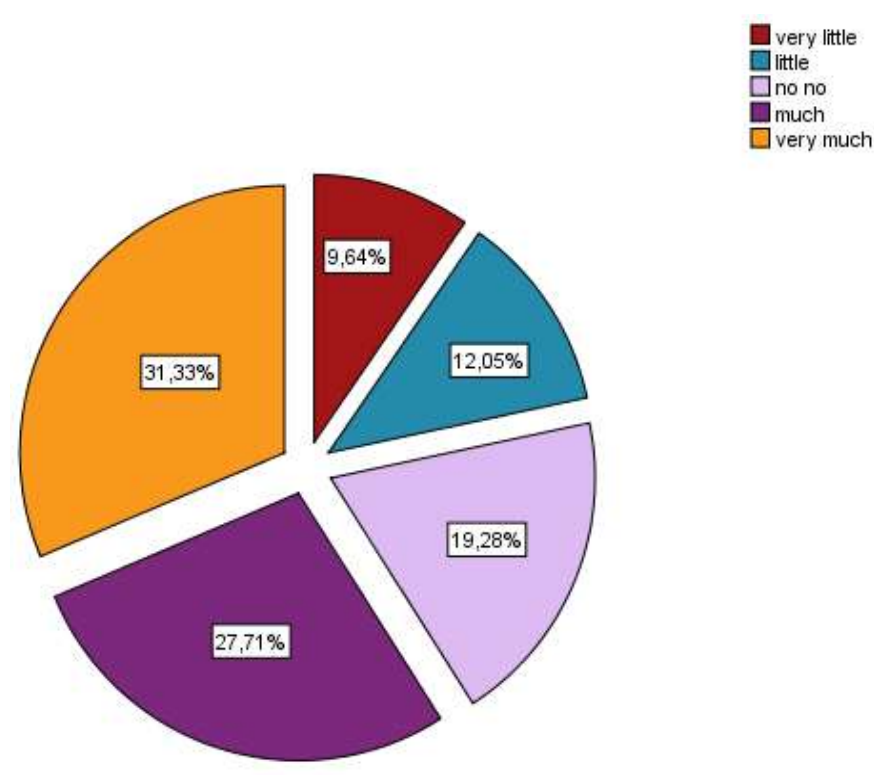

Figure 21: Radio efficiency

Source: author`s computation

From the obtained results we can see that $59,04 \%$ consider that promotion made through radio is efficient for promoting Alba Iulia as a touristic destination. This result can be due to the fact that radio is listened daily, while driving or while performing gymnastics, and the listener comes in contact a few times per day and on different radio stations with the promotional add.

Another important result is consisted from those respondents that couldn't make an opinion, $19,28 \%$, about the efficiency of the radio as a promotional method.
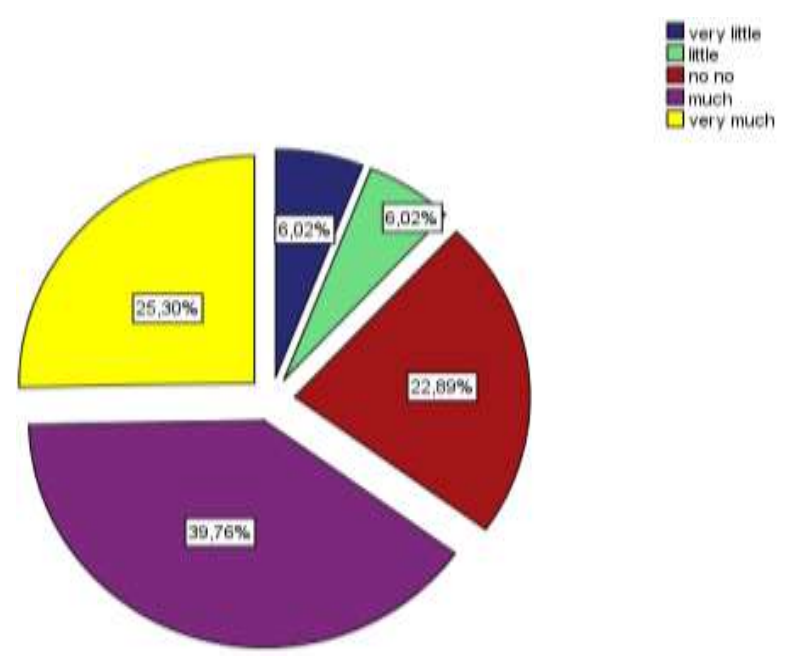

Figure 22: Banners efficiency

Source: author`s computation

From the obtained results we can observe that $39,76 \%$ from the total number of respondents consider that banners are an efficient method for promoting Alba Iulia city as a touristic destination and $25,30 \%$ consider it as being a very efficient method.

We can see also that $22,89 \%$ couldn't form an opinion about the efficiency of this promotional method. 


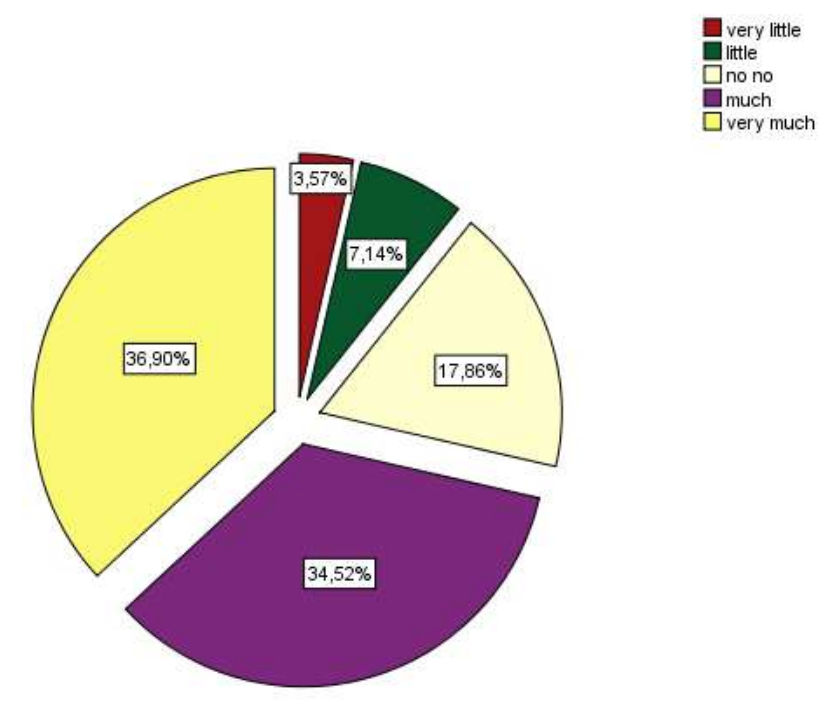

Figure 23: Posters efficiency

Source: author`s computation

From the results we can observe that posters are also considered an important method for promoting Alba Iulia city as a touristic destination by a total number of $71,42 \%$ of the respondents.

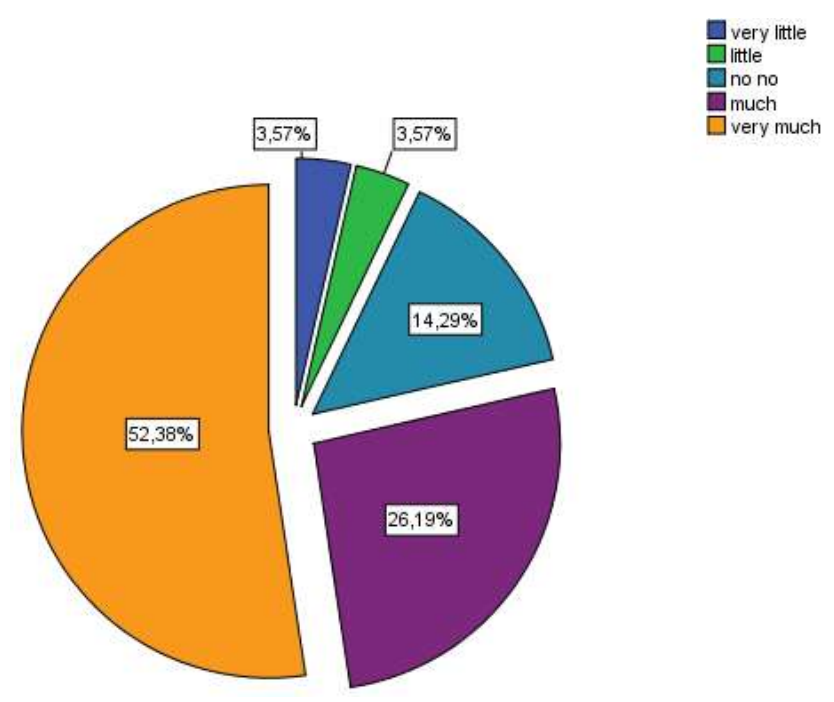

Figure 24: Word of mouth efficiency

Source: author`s computation

From the results we can observe that $52,38 \%$ from the total number of respondents consider this promotional method as being very efficient when it comes to promoting Alba Iulia city as a touristic destination and 26,19\% consider that is an efficient method.

The next question investigated the respondent's opinion regarding the frequency of being announced through the help of the promotional methods about Alba Iulia city. The promotional methods investigated by this question are: facebook, e-mail, travel web sites, tv, radio, banners, posters. The obtained results are presented in the following table. 
Contact with promotional methods

\begin{tabular}{|c|c|c|c|c|c|c|}
\hline $\begin{array}{c}\text { Frequency and } \\
\text { Promotional } \\
\text { method }\end{array}$ & $\begin{array}{c}\text { Several times } \\
\text { per week }\end{array}$ & Once a week & $\begin{array}{c}\text { Once every } \\
\text { weeks }\end{array}$ & Once a month & $\begin{array}{c}\text { Once several } \\
\text { months }\end{array}$ & Once a year \\
\hline facebook & $71,4 \%$ & $10,7 \%$ & $10,7 \%$ & - & $4,8 \%$ & $2,4 \%$ \\
\hline e-mail & $22,6 \%$ & $19,0 \%$ & $21,4 \%$ & $6,00 \%$ & $20,2 \%$ & $10,7 \%$ \\
\hline travel web sites & $8,3 \%$ & $19,0 \%$ & $26,2 \%$ & $16,7 \%$ & $20,2 \%$ & $9,5 \%$ \\
\hline tv & $45,2 \%$ & $16,7 \%$ & $14,3 \%$ & $9,5 \%$ & $7,1 \%$ & $7,1 \%$ \\
\hline radio & $27,7 \%$ & $14,5 \%$ & $18,1 \%$ & $10,8 \%$ & $13,3 \%$ & $15,7 \%$ \\
\hline banners & $22,6 \%$ & $20,2 \%$ & $19,0 \%$ & $19,0 \%$ & $10,7 \%$ & $8,3 \%$ \\
\hline posters & $23,8 \%$ & $19,0 \%$ & $27,4 \%$ & $11,9 \%$ & $13,1 \%$ & $3,6 \%$ \\
\hline
\end{tabular}

Source: author`s computation

From the results we can observe the following:

- $71,4 \%$ received several times per week promotional ads regarding Alba Iulia city

- The e-mail method is almost constantly present throughout a year as a promotional method for receiving touristic information about Alba Iulia city

- Respondents came into contact with travel web sites: once a week (19\%), once every two weeks $(26,2 \%)$ and once several months $(20,2 \%)$

- $45,2 \%$ from the total number of respondents entered into contact with Tv as a promotional method several times per week

- Radio is considered as a promotional method several times per week by a number of $27,7 \%$ and once every week by $18,1 \%$

- Banners are encountered almost constantly throughout a year

- Posters are encountered once every weeks $(27,4 \%)$, several times per week $(23,8 \%)$, once a week $(19 \%)$ and once several months $(13,1 \%)$.

With the help of question number 6 we investigated the respondents' opinion regarding the frequency of which they wish to be announced about touristic events that take place in Alba Iulia city. The obtained results show that $86,9 \%$ from the total number of respondents would like to be informed monthly about the events organized.

Regarding the socio-demographic data the results were the following: from the total number of respondents $71,4 \%$ were female and $28,6 \%$ male; $51,2 \%$ were students, $35,7 \%$ were employed, $8,3 \%$ study master studies, $3,6 \%$ are managers and $1,2 \%$ are volunteers. 57,1 graduated high school, $36,9 \%$ graduated University studies, $3,6 \%$ have master studies and $1,2 \%$ others.

\section{Conclusions}

The most adequate method for promoting tourism activities is Facebook, followed by Tv, radio, e-mail, travel web sites, banners and posters.

In order to maintain a good contact with the potential tourist and increase the visibility of Alba Iulia city as a touristic destination promotion should be conducted several times per week, mainly through Facebook, e-mail, tv, and radio.

Through a consistent and effective management and marketing of tourism destinations, Alba Iulia can become a more attractive and competitive destination.

The marketing activity in the touristic destination has become a serious concern in the process of convincing the tourists to choose Alba Iulia city as a destination for their leisure time that they have. 


\section{References}

1. Bjork, P., 2012. Brand Recovery: A Quick Fix Model for Brand Structure Collapse, Journal of Travel \&Tourism Marketing, 29(6), 520-531.

2. Chikafu Jesca, Kumbirai Mirimi, Hurombo Brigthon, 2014. Destination rebranding paradigm in Zimbabwe: A Stakeholder Approach, International Journal of Advanced Research in Management and Social Sciences, Vol.3, No. 1, 30-41.

3. Hosany S., Ekinci, Y., Uysal M., 2006. Destination image and destinationa personality: An apllication of branding theories to tourism places, Journal of Business Research, 59(5), 638642.

4. Ivo Mulec, 2010. Promotion as a Tool in Sustaining the Destination Marketing Activities, Turizam, Vol. 14, issue 1, 13-21.

5. Kotler, Ph., Armstrong, G., 2010. Principles of Marketing, thirteenth edition, Pearson Education, Inc., New Jersey.

6. Kolb, M.(2006), Tourism marketing for cities and towns: using brands and events to attract tourists, USA, Butterworth-Heinemann Publications.

7. The International Labour Office, 2012., Toolkit on Poverty Reduction through Tourism, Training Package Teaching Notes, Module 3 Promotion and marketing in tourism, available at http://www.ilo.org/wcmsp5/groups/public/---ed_dialogue/--sector/documents/instructionalmaterial/wcms_218329.pdf (12.11.2016)

8. http://viziteazaalbaiulia.ro/muzeul-national-al-unirii-printre-cele-mai-vizitate-muzee-dinromania/

9. http://ec.europa.eu/growth/tools-databases/eden_en

10. http://viziteazaalbaiulia.ro/orasul-in-care-viitorul-prinde-radacini-premiat-la-gala-turismuluiromanesc-2016/

11. https://www.roughguides.com/features/

12. http://ziarulunirea.ro/alba-iulia-oras-pilot-pentru-promovarea-turistica-neconventionala-382414/ 